Bull. Mater. Sci. Vol. 13, No. 3, June 1990, pp. 205-210. (C) Printed in India.

\title{
Studies on transmission behaviour of certain manganese containing, cerium and arsenic doped alkali-lime-silica glasses*
}

\author{
S A MUQTADER, S N ALVI, M A JALEEL and S G SAMDANI + \\ Indian Institute of Chemical Technology, Hyderabad 500007 , India \\ ${ }^{+}$College of Technology, Osmania University, Hyderabad 500 007, India \\ MS received 6 November 1989; revised 9 March 1990
}

\begin{abstract}
The transmission behaviour of manganese containing alkali-lime-silica glasses have been investigated with and without $\mathrm{CeO}_{2}$ and $\mathrm{As}_{2} \mathrm{O}_{3}$ as dopants. The changes taking place owing to irradiation with solar and ultra-violet conditions are reported and the roles of arsenic and ceria in causing the observed changes are discussed.
\end{abstract}

Keywords. Glasses; transmission; arsenic; ceria; manganese; alkaline oxides.

\section{Introduction}

Manganese is usually present in glass as the bivalent manganous $\mathrm{Mn}^{2+}$ and trivalent manganic $\mathrm{Mn}^{3+}$ states which impart colours in the glass. The nature of the transmission curves in the visible range depends mainly upon the constituents of the glass (Bancraft and Nugent 1929). Ceria is believed to trible the decolorising power of manganese; while arsenic reduces manganic ion and is also reported to act as an oxidation reduction buffer, thus stabilizing the colour due to manganese in glass. Under suitable conditions $\mathrm{Ce}^{4+}$ oxidizes $\mathrm{Mn}^{2+}$ (Weyl 1951).

The change in transmission due to the exposure to radiation has been discussed by Weyl (1951) who has offered an explanation for the action of sunlight on glasses containing manganese, and the formation of the yellow and the purple hues. Sodalime glasses containing $\mathrm{As}_{2} \mathrm{O}_{3}, \mathrm{CeO}_{2}, \mathrm{MnO}_{2}$ and $\mathrm{Sb}_{2} \mathrm{O}_{3}$ and with low and high iron contents were also reported by White and Silverman (1950). The effect on transmission after irradiation is pronounced in the case of glasses having low iron contents and it is marginal in the high iron containing glasses.

The shifting of maximum absorption towards higher wavelengths with increasing ionic radii of the alkali ions in the order $\mathrm{Li}^{+}<\mathrm{Na}^{+}<\mathrm{K}^{+}$, in alkali-silicate glass has been explained (Kumar and Singh 1989).

The purpose of the present investigation is primarily to determine the transmission behaviour of manganese containing alkali-lime-silica glasses with and without $\mathrm{CeO}_{2}$ and $\mathrm{As}_{2} \mathrm{O}_{3}$ as dopants. Emphasis has been laid on determination of the behaviour of transmission changes due to ultra-violet and solar radiations.

\section{Experimental}

Ternary glasses of molar compositions $2 \mathrm{R}_{2} \mathrm{O} \cdot 3 \mathrm{CaO} \cdot 6 \mathrm{SiO}_{2}$ (where $\mathrm{R}=\mathrm{Li}^{+}, \mathrm{K}^{+}$ions) were selected as the base glasses. Raw materials used for the preparation of glasses were analar grade alkali carbonates, calcium carbonate and pure sand. Manganese,

*IICT Communication No. 2499. 
cerium and arsenic were added to batches as $\mathrm{MnO}_{2}, \mathrm{CeO}_{2}$ and $\mathrm{As}_{2} \mathrm{O}_{3}$ respectively. Batch compositions are shown in table 1.

The batches were weighed and mixed thoroughly in a porcelain pestle and motar. The glasses were prepared by melting the batches in the siliminate crucibles, in an electric muffle furnace. Samples of these glasses were obtained in the form of a disc by pouring the molten glass onto a steel plate. These discs were then annealed and ground to the shape of rectangular plates $3.5 \times 0.9 \times(0.25-0.35) \mathrm{cm}^{3}$, and then polished.

Spectrophotometric measurements were carried out using UV-Vis Shimadzu 240 Spectrophotometer, for all the glass samples in the visible range $(300-700) \mathrm{nm}$ of the spectrum, before and after exposure to ultraviolet and solar radiations. Ultraviolet and solar treatments were given for $4 \mathrm{~h}$ and 15 days respectively. Since the thickness of the samples varies over a range of 0.25 to $0.35 \mathrm{~cm}$, thickness correction has been made for all the samples using the Bouguer's Law. Accordingly to this law, $T=t^{x}$ where $T=$ light transmission of a material of thickness $x$ having a unit transmission $t$. The transmission for all samples, calculated for a standard thickness of $0.3 \mathrm{~cm}$, at $10 \mathrm{~nm}$ intervals in wavelength (for exposed and unexposed glasses), are indicated in the graphs.

\section{Discussion and conclusion}

The percentage transmission obtained for the various glass compositions under varying experimental conditions are indicated in table 2 and figures 1-7.

From figure 1 it is clear that in all the cases the addition of ceria as well as arsenic shifts the wavelength of maximum transmission towards the higher side as compared to the base composition. However, in the case of glasses containing arsenic, the shifting of transmission was from higher to lower wavelengths for lithia and potash containing glasses, respectively, while this effect was reversed in the case of ceria additions (table 2). Although it has been reported by earlier workers (Kumar and Singh 1989) that the shift is due to increase in the ionic radii, it seems that the addition of arsenic in the base glass under investigation reverses this effect

Table 1. Batch compositions of glasses, along with melting temperature, time and annealing temperatures.

\begin{tabular}{lcccccc}
\hline & \multicolumn{7}{c}{ Glass number } \\
\cline { 2 - 7 } Materials & I & II & III & IV & V & VI \\
\hline Lithium carbonate & 25.07 & - & 25.07 & - & 25.07 & - \\
Potassium carbonate & - & 38.58 & - & 38.58 & - & 38.58 \\
Calcium carbonate & 51.05 & 41.90 & 51.05 & 41.90 & 51.05 & 41.90 \\
Sand & 61.19 & 50.32 & 61.19 & 50.32 & $61 \cdot 19$ & 50.32 \\
Manganese dioxide & 0.5 & 0.5 & 0.5 & 0.5 & 0.5 & 0.5 \\
Cerium dioxide & - & - & 1.0 & 1.0 & - & - \\
Arsenic trioxide & - & - & - & - & 1.0 & 1.0 \\
Melting point $\left({ }^{\circ} \mathrm{C}\right)$ & 1360 & 1400 & 1360 & 1400 & 1360 & 1400 \\
Melting time (h) & 1.5 & 1.5 & 1.5 & 1.5 & 1.5 & 1.5 \\
Annealing temperature $\left({ }^{\circ} \mathrm{C}\right)$ & $450-$ & $450-$ & $450-$ & $450-$ & $450-$ & $450-$ \\
& 500 & 500 & 500 & 500 & 500 & 500 \\
\hline
\end{tabular}


Table 2. Relation between ionic radii of alkali ion with maximum transmission $\%$ and dopant oxides.

\begin{tabular}{|c|c|c|c|c|c|c|c|c|}
\hline \multirow[b]{2}{*}{ Glass composition } & \multirow{2}{*}{$\begin{array}{l}\text { Thick- } \\
\text { ness of } \\
\text { sample } \\
\text { (cm) }\end{array}$} & \multirow{2}{*}{$\begin{array}{c}\text { Ionic } \\
\text { radii } \\
\text { of alkali } \\
\text { ion } \\
(\AA)\end{array}$} & \multicolumn{2}{|c|}{$\begin{array}{c}\text { Dopant } \\
0.5 \mathrm{wt} \% \mathrm{MnO}_{2}\end{array}$} & \multicolumn{2}{|c|}{$\begin{array}{c}\text { Dopants } \\
0.5 \mathrm{wt} \% \mathrm{MnO}_{2} \\
1.0 \mathrm{wt} \% \mathrm{CeO}_{2}\end{array}$} & \multicolumn{2}{|c|}{$\begin{array}{c}\text { Dopants } \\
0.5 \mathrm{wt} \% \mathrm{MnO}_{2} \\
1.0 \mathrm{wt}^{\circ} \% \mathrm{As}_{2} \mathrm{O}_{3}\end{array}$} \\
\hline & & & $\begin{array}{l}\text { Wavelength } \\
\text { (nm) }\end{array}$ & $\begin{array}{l}\text { Max. } \\
\operatorname{tr} \% *\end{array}$ & $\begin{array}{c}\text { Wavelength } \\
\text { (nm) }\end{array}$ & $\begin{array}{l}\text { Max. } \\
\operatorname{tr} . \%\end{array}$ & $\begin{array}{l}\text { Wavelength } \\
\text { (nm) }\end{array}$ & $\underset{\text { tr. } \%}{\text { Max. }}$ \\
\hline $2 \mathrm{Li}_{2} \mathrm{O} \cdot 3 \mathrm{CaO} \cdot 6 \mathrm{SiO}_{2}$ & 0.3 & $0.60\left(\mathrm{Li}^{+}\right)$ & 400 & $29 \cdot 5$ & 410 & 21 & 450 & 75 \\
\hline $2 \mathrm{~K}_{2} \mathrm{O} \cdot 3 \mathrm{CaO} \cdot 6 \mathrm{SiO}_{2}$ & $0-3$ & $1 \cdot 33\left(\mathrm{~K}^{+}\right)$ & 403 & $35 \cdot 5$ & 450 & $52 \cdot 5$ & 410 & 84 \\
\hline
\end{tabular}

tr. $=$ transmission.

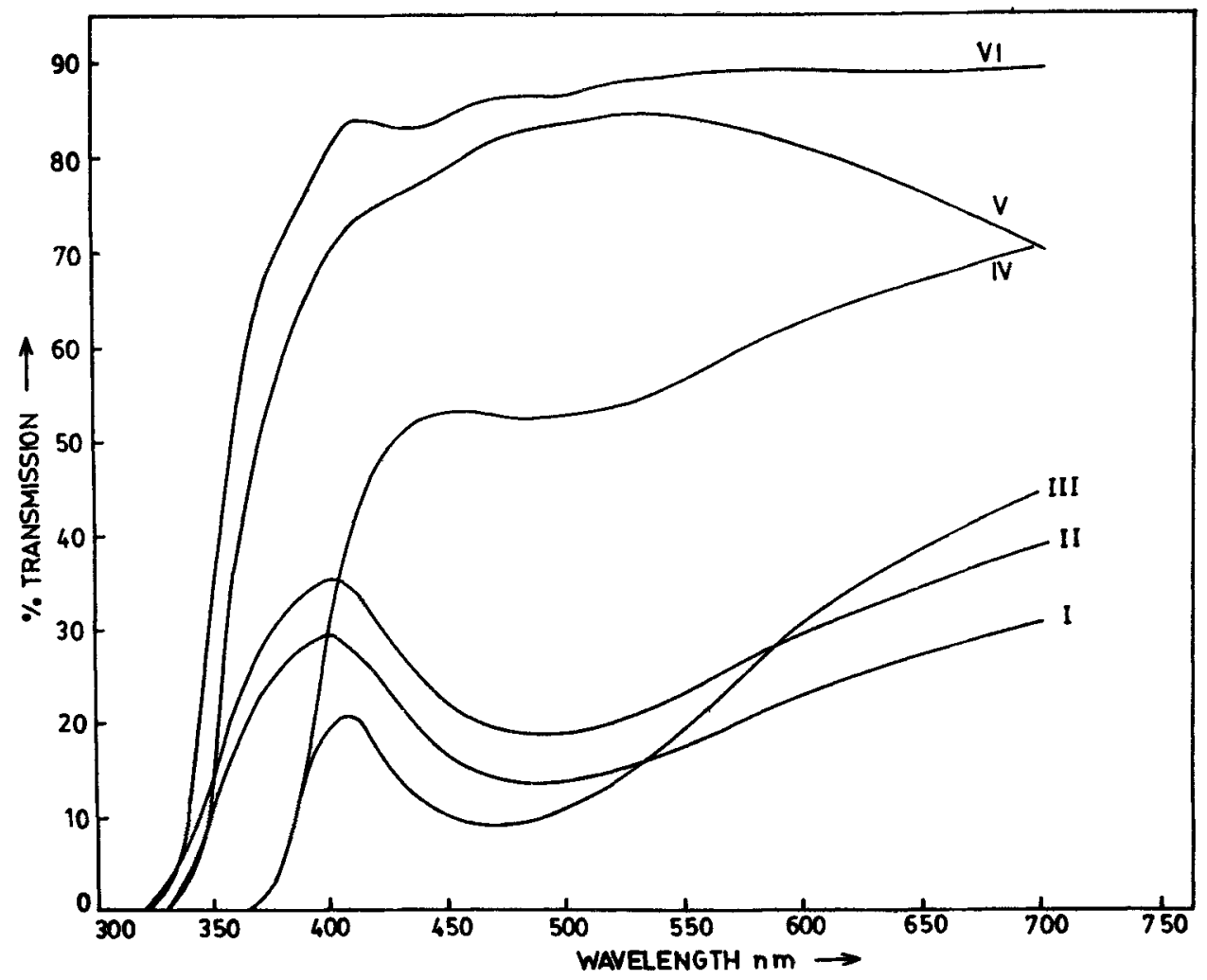

Figure 1. Transmission curves of alkali-lime-silica glasses: (I) lithium, (II) potassium with $0.5 \mathrm{wt} \% \mathrm{MnO}_{2}$; (III) lithium, (IV) potassium with 0.5 wt $\% \mathrm{MnO}_{2}+1$ wt $\% \mathrm{CeO}_{2}$; (V) lithium, (VI) potassium with $0.5 \mathrm{wt} \% \mathrm{MnO}_{2}+1 \mathrm{wt} \% \mathrm{As}_{2} \mathrm{O}_{3}$ (sample thickness $3 \mathrm{~mm}$ ).

which could be due to the varying oxidation state of arsenic and would require detailed investigation.

Other observations based on our experimental results were as follows:

(i) In all cases the percentage transmission in potash containing glasses was higher. (ii) The transmission in the case of arsenic containing glasses was higher when compared to ceria-containing glasses. 


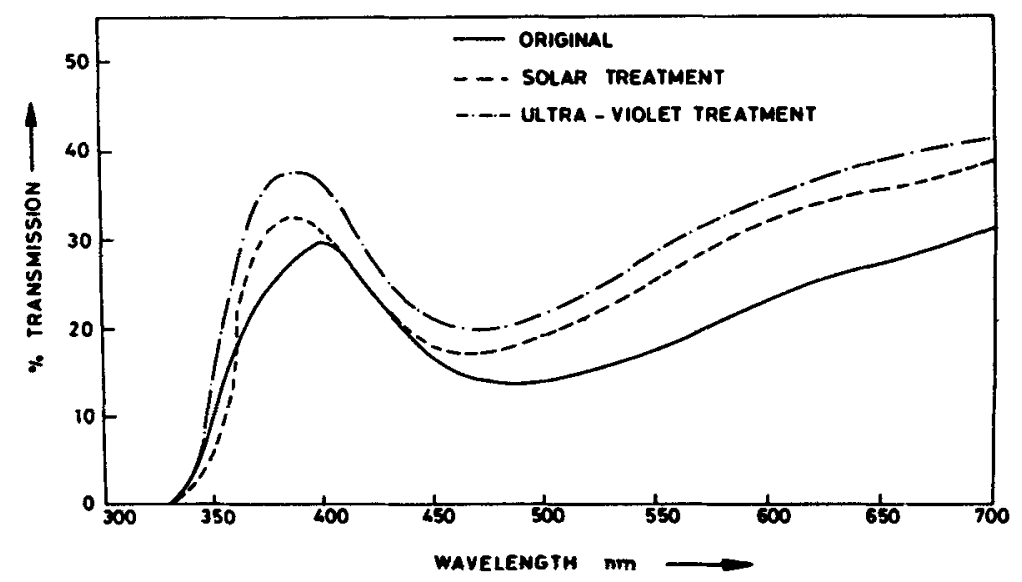

Figure 2. Effect of solar and ultraviolet radiations on lithium-lime-silica glass with $0.5 \mathrm{wt} \% \mathrm{MnO}_{2}$ (sample thickness $3 \mathrm{~mm}$ ).

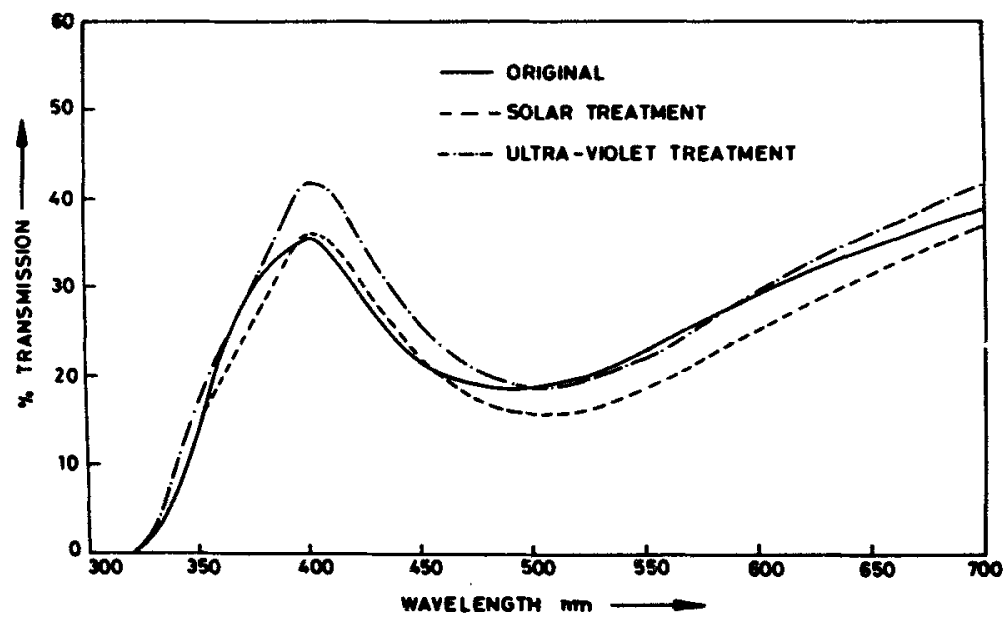

Figure 3. Effect of solar and ultraviolet radiations on potassium-lime-silica glass with $0.5 \mathrm{wt} \% \mathrm{MnO}_{2}$ (sample thickness $3 \mathrm{~mm}$ ).

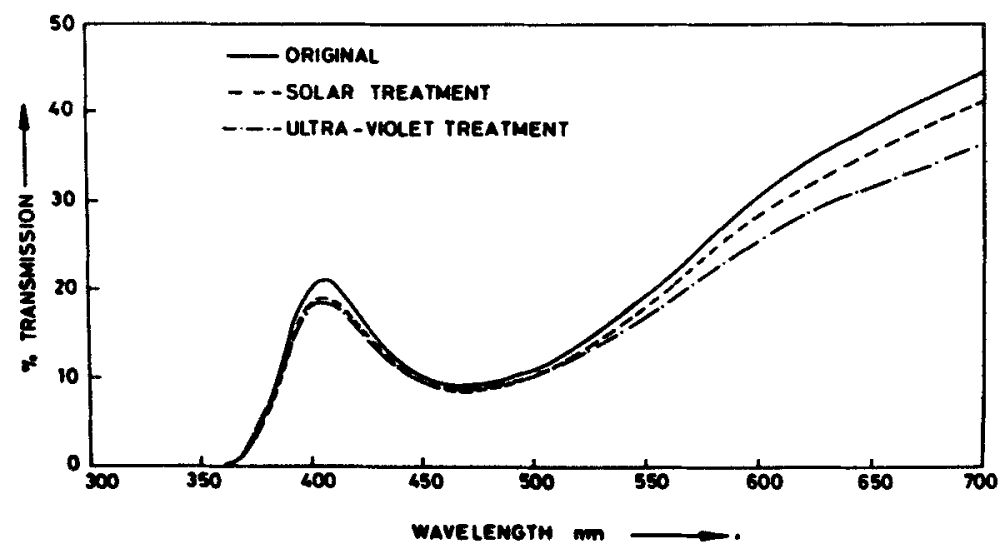

Figure 4. Effect of solar and ultraviolet radiations on lithium-lime-silica glass with $0.5 \mathrm{wt} \% \mathrm{MnO}_{2}$ and $1 \mathrm{wt} \% \mathrm{CeO}_{2}$ (sample thickness $3 \mathrm{~mm}$ ). 


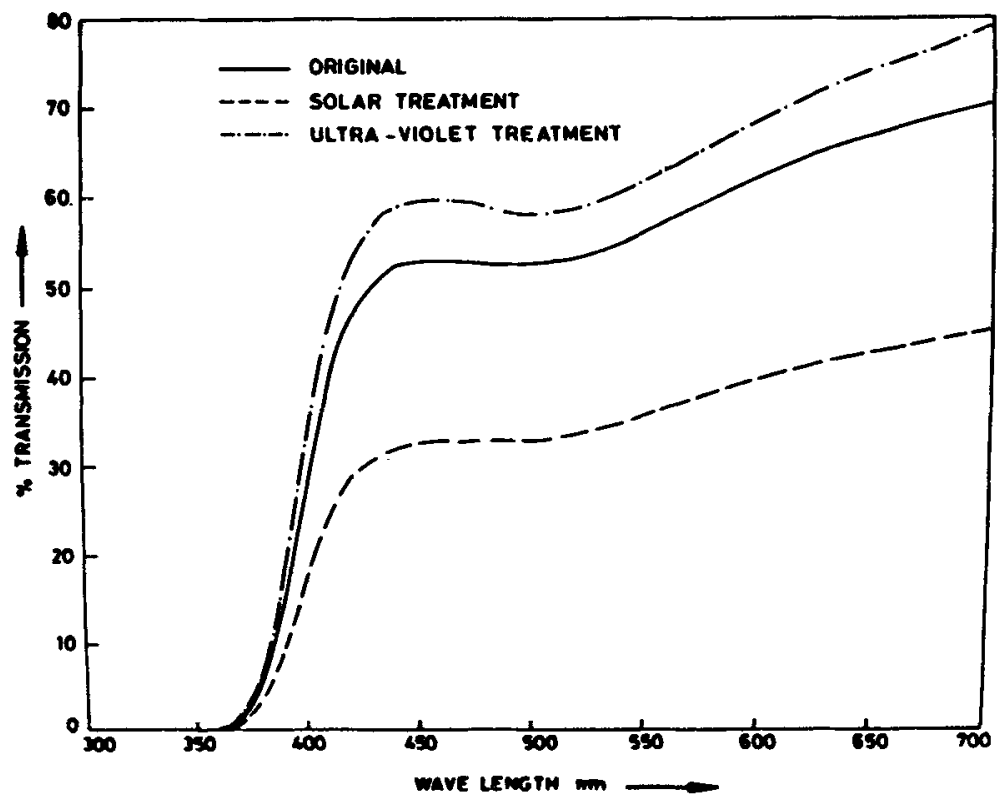

Figure 5. Effect of solar and ultraviolet radiations on potassium-lime-silica glass with $0.5 \mathrm{wt}^{\circ} \% \mathrm{MnO}_{2}$ and $1 \mathrm{wt}^{\%} \mathrm{CeO}_{2}$ (sample thickness $3 \mathrm{~mm}$ ).

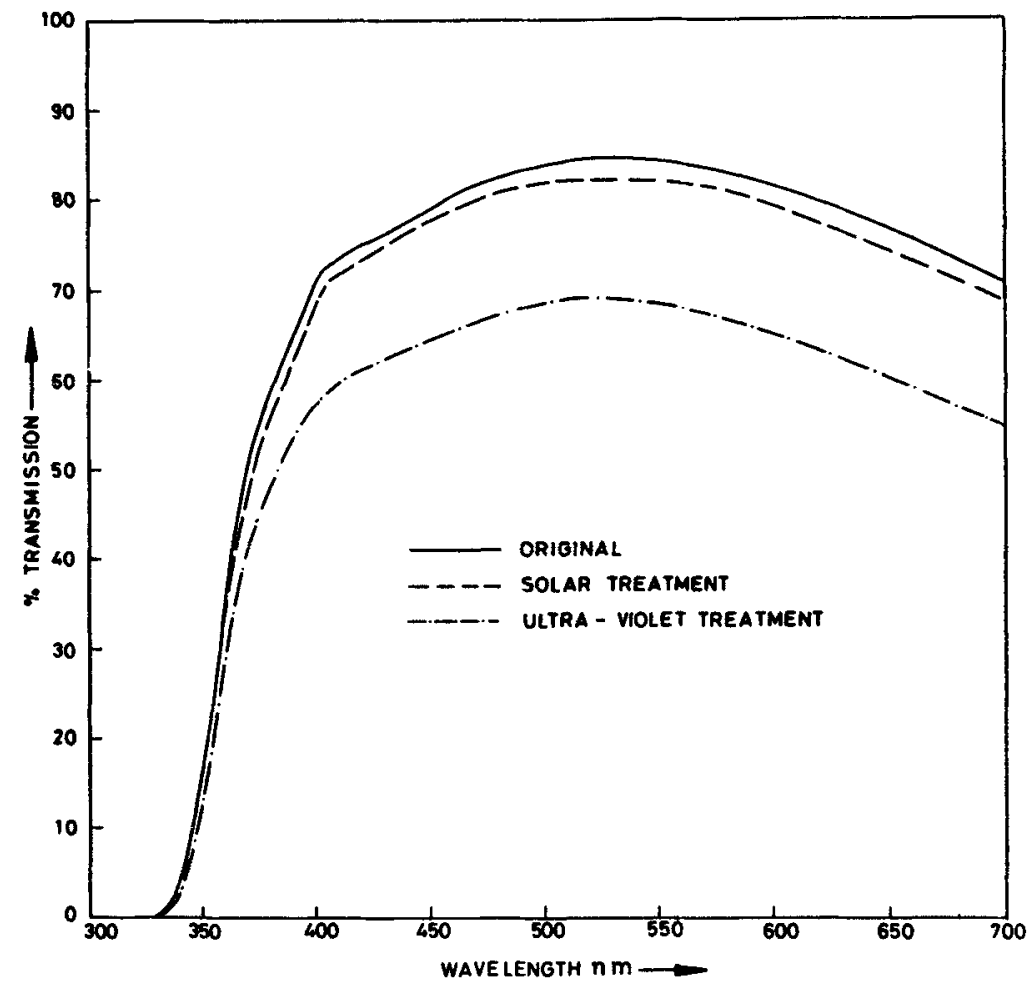

Figure 6. Effect of solar and ultraviolet radiation on lithium-lime-silica glass with $0.5 \mathrm{wt}_{0} \% \mathrm{MnO}_{2}$ and $1 \mathrm{wt} \% \mathrm{As}_{2} \mathrm{O}_{3}$. 


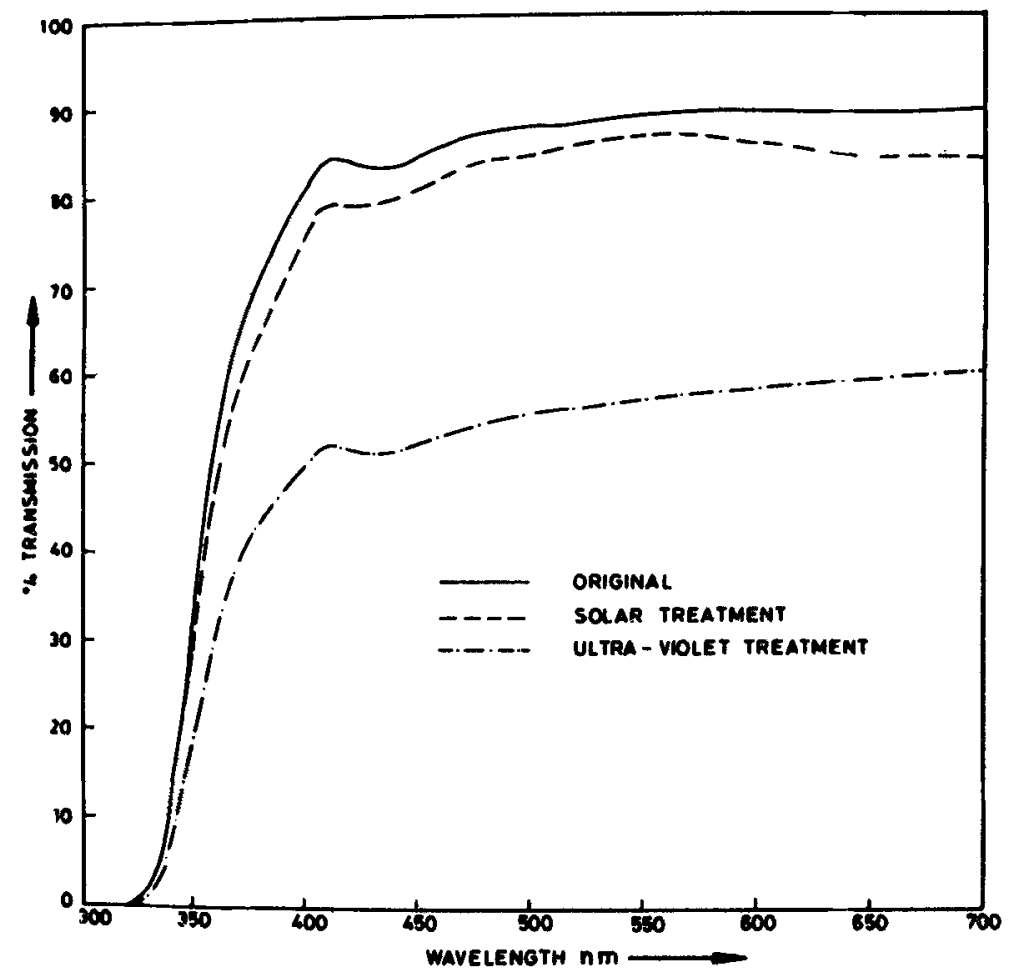

Figure 7. Effect of solar and ultraviolet tradition on potassium-lime-silica glass with $0.5 \mathrm{wt} \% \mathrm{MnO}_{2}$ and $1 \mathrm{wt} \% \mathrm{As}_{2} \mathrm{O}_{3}$.

(iii) The base glass has a marginal effect on the nature of transmission after solar and ultraviolet irradiations (figures 2-3). The same trend is found in the case of base glasses containing ceria (figures 4-5).

(iv) The addition of arsenic alone in the base glass has a pronounced effect on the nature of the transmission curves after ultraviolet irradiation (figures 6-7) and has a marginal effect in the case of solar irradiation, this could be due to the ease with which electron can be liberated from arsenic.

\section{Acknowledgements}

One of the authors (SAM) is grateful to the Council of Scientific and Industrial Research, New Delhi for the award of a fellowship. Authors are thankful to Dr A V Rama Rao for encouragement. Authors are also thankful to Mr M A Wahab for his keen interest in the initial stages of this work.

\section{References}

Bancraft W D and Nugent R L 1929 J. Phys. Chem. 33481

Kumar A and Singh S P 1989 Trans. Indian Ceram. Soc. 4839

Weyl W A 1951 Coloured glasses (Sheffield: Society of Glass Technology) p. 121

White J F and Silverman W B 1950 J. Am. Ceram. Soc. 33252 